Original Research Paper

\title{
PCR Diagnosis for the Identification of the Virulent Gene of Salmonella in Poultry Meat
}

\author{
${ }^{1}$ D. K. Zhanabayeva, ${ }^{1 *}$ A. Y. Paritova, ${ }^{1}$ G. K. Murzakaeva, ${ }^{1}$ A. A. Zhanabayev, \\ ${ }^{2}$ A. Kereev, ${ }^{1}$ Zh. S. Asauova and ${ }^{3}$ M. Zh. Aubakirov \\ ${ }^{1}$ S. Seifullin Kazakh Agrotechnical University, Nur-Sultan, Republic of Kazakhstan \\ ${ }^{2}$ West Kazakhstan Agrarian Technical University named after Zhangirkhan, Uralsk, Republic of Kazakhstan \\ ${ }^{3}$ Kostanay State University named after A. Baitursynova, Kostanay, Republic of Kazakhstan
}

Article history

Received: 04-05-2021

Revised: 07-07-2021

Accepted: 09-07-2021

Corresponding Author:

A. Y. Paritova,

S. Seifullin Kazakh

Agrotechnical University, Nur-

Sultan, Republic of Kazakhstan

Email: paritova87@mail.ru

\begin{abstract}
The purpose of this study was to conduct microbiological studies of poultry meat imported into Mongolia and establish the serotypes and plasmids of Salmonella and determine the virulence of the gene encoding antibiotic resistance and its transmigratory properties. The PCR molecular biological method was used and according to the results, Salmonella enteritidis was identified in chicken carcasses of the American company, Tyson, the Chinese firm, Xilingol and a domestic company. On detection of pathogenic microbes in the chicken meat, the following data were obtained: Salmonella and Escherichia coli were found in samples from Tyson, with the participation of the company, Capital Market, from the wagon number MWCU521698. All this pointed to the possibility of the contamination of food before entering Mongolia. Salmonella and E. coli were identified in samples from the Russian company, Leghorn, while E. coli was found in Xilingol chickens sold on the Mercury food market. E. coli was also found in chicken meat from the workshop of the Mongolian firm, Tumen Shuvuut. Salmonella and Pseudomonos were then pinpointed at the Khuchit Shonkhor meat market, which indicated an increase in microbial contamination of chicken meat during the marketing and transportation stages. Microbiological research into Tyson's frozen chicken meat, with the participation of Capital Market and Xilingol, showed that the total number of microbes exceeded 3-3.5 times the standard MNS6308: 2012. We identified invA genes and DT 104 Salmonella plasmids using PCR. The detection of antibiotic resistance of Salmonella isolated from chicken meat was established by the DNA sequence for chloramphenicol $878 \mathrm{bp}$, for ampicillin-692 bp, for sulfatomycin-293 bp. From the above data, it follows that chicken meat was heavily contaminated with various pathogenic bacteria before entering the Mongolian market.
\end{abstract}

Keywords: Sequences, Aviculture, Food Poisoning, Cultivation, Salmonella Serotypes, Pathogenicity, Drug Resistance, Antibiotics, DNA Detection

\section{Introduction}

Over the past 20 years, the increase of food poisoning infections has caused damage to human health and the economies in many countries around the world. An epidemiological study of the National Commission for Digestive Diseases (U.S.) reported that the rate of age-adjusted hospitalizations from gastrointestinal infections increased by $92.8 \%$ between 1979 (76.1 per $100,000)$ and $2004(146.7$ per 100,000). With the rising incidence and severity of Clostridium difficile infection, the morbidity and mortality are expected to increase further. (Everhart and Ruhl, 2009).
The prevalence of diseases caused by Salmonella in the U.S. (Strawn et al., 2014) is about 1.4 million times per year (Lynch et al., 2009), in Europe it was detected in 95548 individuals (Janecko et al., 2015) and in China and England (D'Aoust and Maurer, 2007). The main origins of food infection are a Salmonella spp, Listeria monocytogens, Escherichia coli (E. coli) O157: H7 and Staphylococcus aureus (Norman et al, 2013).

Poultry meat and products contain large amounts of contaminants, such as microscopic fungi and mycotoxins. These are widely found in grain products, antibiotics and hormonal preparations that are used for 
the treatment and stimulation of the productive qualities of animals (Kwang et al., 1996).

Polymerase Chain Reaction (PCR) is the most extensive method in molecular biology and used to determine and study the safety of meat. It has already been used before for the detection of Salmonella and other microorganisms in food samples and established itself as a very precise tool for their identification (Garrido et al., 2013). The presence of plasmids in more than 100 species of microbes and molecules of DNA plasmids contain 2,000-4,000 based pairs. Toxic plasmids of 30-90 D weight of molecules consist of DNA sites, separated from chromosomes that are in the cytoplasm. Not all types of Salmonella are plasmids. The presence of toxic plasmids has been revealed in $S$. typhimurium, $S$. dublin, $S$. gallinarium-pullorum, S. enteritidis, S. abortuseque and S. choleraesuis (Wang et al., 1997).

The description of the bacteriological contamination of meat products varies depending on the climatic conditions, economic level and quality control. When infected meat is bought, Salmonella is found in the inner layers of the muscle tissue (Tibaijuka et al., 2002). A high degree of contamination (Salmonella 11\%, Campylobacter 57\%) was reported from 1995-2000 in Australia (Whyte et al., 2002). In 1998, Salmonella accounted for $6 \%$ of the infections in the southern region of the United States, while $47-81 \%$ was due to Campylobacter (Poppe et al., 1998).

The handling of poultry meat in its raw state can be dangerous, as Salmonella survives for a long time in raw meat. The sensitivity PCR is high when determining for Salmonella (Wilson, 2002). From 1996-2000, research was conducted on poultry meat for the presence of Salmonella and S. entenberg 10,3\%, S. habar 6,8\%, S. agona $5,1 \%$ and $S$. typhimurium $2,4 \%$ were found in the samples (Tavechio et al., 2002). In another study, Salmonella was also found in poultry meat $21.7 \%$, water $6.6 \%$ and animal feed $4,4 \%$ (Lin and Tsen, 1996) In similar studies, it was found that $3.7 \%$ of poultry meat was contaminated with Salmonella, $4.2 \%$ of beef and 1,7\% of horsemeat (Khosrof et al., 2002). In 2001, 825 samples of poultry meat showed Salmonella and E. coli. (Zhao et al., 2001). In the city of Ankara, 140 samples were selected in the supermarket: 50 samples of whole birds, 30 samples of the front part, 30 of the femoral part and 30 of the ribs and research was carried out for the presence of Aeromonas. These microorganisms were found in 116 samples (82.9\%) (Sarimehmetoglu and Kuplulu, 2001).

According to the results of microbiological studies of chicken, American scientists have found the Tryptic Soy Agar (TSA) microorganisms, Staphylococcus coliform, E. coli and certain colonies, in a nutrient medium (Worcman-Barninka et al., 2001).

The challenges of poultry meat contamination are relevant today. Scientific research into the poultry industry of developing countries have not been made. For the first time, comparative studies were conducted and data obtained on the quality and safety of poultry meat. The studies were conducted at the molecular level and are very important for the industry of these countries.

The aim of this study was to undertake microbial research into poultry sold on the territory of Mongolia and to identify Salmonella serotypes and plasmids, to determine the virulence gene coding for antibiotic resistance and transmigration properties of Salmonella.

\section{Methods}

For DNA isolation we used the Lysis buffer-PCI method.

\section{DNA Isolation Lysis Buffer-PCI method}

First, a piece of the base feather was cut and inserted in a $1.5 \mathrm{~mL}$ microtube, then $500 \mu \mathrm{L}$ of lysis buffer and proteinase K by $175 \mu \mathrm{g} \cdot \mathrm{mL}^{-1}$ was added. Subsequently, the sample was incubated at $37^{\circ} \mathrm{C}$ overnight. After that, the sample was centrifuged at $13,000 \mathrm{rpm}$ for 10 ( $\mathrm{min}$ ). The supernatant was transferred to a new $1.5 \mathrm{~mL}$ microtube, $700 \mu \mathrm{L}$ of PCI was added, then vortexed for $30 \mathrm{~s}$ and incubated in the ice box for $10 \mathrm{~min}$. The supernatant was then centrifuged at 13,000 rpm for $5 \mathrm{~min}$. It was transferred to a new microtube, $600 \mu \mathrm{L}$ of chloroform-isoamyl alcohol (24:1) was added, vortexed at $30 \mathrm{~s}$ and then incubated in the ice box for $10 \mathrm{~min}$. After that, the supernatant was centrifuged $13,000 \mathrm{rpm}$ for $3 \mathrm{~min}$ and transferred to a new microtube. Then, $95 \%$ ethanol, twice the volume of the supernatant, was added, as well as $50 \mu \mathrm{L}$ of $\mathrm{NaCl}$, after which it was incubated in the freezer for $15 \mathrm{~min}$. After that, it was centrifuged at 13,000 rpm for $10 \mathrm{~min}$. Next, the supernatant was removed and the pellet was added with $500 \mu \mathrm{L}$ of $70 \%$ ethanol. The suspension was then incubated in the freezer for $15 \mathrm{~min}$ and centrifuged at 13,000 rpm for $10 \mathrm{~min}$, after which the supernatant was removed until no ethanol remained. Finally, pellets were added with $25 \mu \mathrm{L}$ of Tris-EDTA (TE) for dilution (Everhart and Ruhl, 2009; Gallardo et al., 2003).

Before transportation, poultry meat should be and kept at temperatures below $4^{\circ} \mathrm{C}$ or $40^{\circ} \mathrm{F}$. Research was carried out in the laboratory of Ulan Bator, Mongolia (47 $54^{\prime} 27$ "N 106 52'59" E).

The following objects were part of this study: A total of 198 samples from the slaughterhouse, of which 4 were chilled samples, 8 frozen samples from depositors $\left(-120^{\circ} \mathrm{C}\right)$ and samples of thawed meat from the Mercury market. Samples were taken at all stages of the Tymen shuvuut aviculture. Frozen samples of US origin, China, Kazakhstan and the Russian Federation were taken from the container and shopping centers of Ulan Bator.

\section{Sample selection}

The 198 samples were tested after the slaughter of birds in slaughterhouses. The radiation method was used 
to test 32 samples, of $16 \%$ contained Salmonella. In general, Salmonella was found in 45 of the 198 samples.

The samples were disintegrated, turned into suspensions and sowed on Petri dishes with sterile normal nutrient medium with $1 \mathrm{~mL}$, each diluted 2-3 times. The crops were placed in a thermostat at a temperature of $37^{\circ} \mathrm{C}$ for $24 \mathrm{~h}$ to develop the cultures. After this time, the Petri dishes were divided into sectors of $1 \mathrm{~cm}^{2}$, the number of colonies in the sectors were diagonally counted with the help of semi-automatic counters and the average number of colonies for one sector and on the entire area of the dish, was calculated using the formula:

$\mathrm{S}=\pi \mathrm{r}^{2}$

$\mathrm{S}-$ area of a sector of a circle

$\pi-$ number of $p i$

$\mathrm{r}^{2}-$ radius square

To determine the microbial number, the dilution denominators multiplied the result of the count of the number of colonies in the petri dish and the computed arithmetic mean of the obtained numbers was calculated, the result was the number of bacteria in the test portion. Then the number of germs in $1 \mathrm{~g}$ of the sample was established. To determine the qualitative composition, colonies of microbes were selected which had grown on a conventional medium, having the form of $R, S$ and pigmentation. The selected colonies were cultured for 24-72 $\mathrm{h}$ in a liquid enriched media: Lauryl sulfate tryptose broth (Sigma Aldrich, USA), lactose bile broth (Sigma Aldrich, USA), Rapports broth (Alpha BioSciences, USA) and nutrient broth (Sigma Aldrich, USA).

\section{DNA Extraction}

For DNA extraction, $1 \mathrm{~g}$ of raw chicken was ground. The samples from the processed meat were heated at a temperature of $1,000^{\circ} \mathrm{C}$ for $30 \mathrm{~min}$ and cooled. The magnitude and the purification of the isolated DNA were measured by the UV-265 spectrophotometer (Shimadzu) at the wavelength of light of 260 and $280 \mathrm{~nm}$. Nucleic acid absorbs the ultraviolet rays of $260 \mathrm{~nm}$, which were measured by the photodetector.
Meat frozen by liquid nitrogen (4.1 g) was comminuted in a mortar, placed into the cylinder with 500 $\mu \mathrm{L}$ of lysis buffer and incubated at a temperature of 55$560^{\circ} \mathrm{C}$ for $2-3 \mathrm{~h}$. Proteinase $\mathrm{K}(6-12 \mu \mathrm{L})$ was added and it was heated at $370^{\circ} \mathrm{C}$ for $30 \mathrm{~min}$, as well as the $500 \mu \mathrm{L}$ combination of phenol with chloroform, thoroughly mixed and centrifuged for $10 \mathrm{~min}$ with 1,500 turnover. The upper layer was put into a sterile mixture cylinder, with $99 \%$ ethyl alcohol added, $30 \mu \mathrm{L}$ of $3 \mathrm{~m} \mathrm{NaCl}$ and held at $25-300^{\circ} \mathrm{C}$ for $20 \mathrm{~min}$. Next, centrifugation at $40^{\circ} \mathrm{C}$ for 15 min with 1,500 turn over. The liquid part of the upper layer was decanted, to the residue $400 \mu \mathrm{L}$ of $70 \%$ alcohol was added, which was then centrifuged at $40^{\circ} \mathrm{C}$ for $5 \mathrm{~min}$. The upper layer liquid was decanted and the DNA residue was dried in air for $10-15 \mathrm{~min}$. The residue of dried DNA was retained in 25-50 ulof 1xTE (Tris EDTA) buffer at a temperature of $40^{\circ} \mathrm{C}$, with prolonged storage at $20^{\circ} \mathrm{C}$.

\section{PCR}

In determining the presence of pathogens in meat, a PCR assay was used to detect the presence of Salmonella. A Multiplex PCR was used (IHC, USA). When the PCR account was taken, $25 \mu \mathrm{L}$ were taken per amplification unit. The mixture was prepared as follows: $800 \mathrm{ng}$ of DNA template, $25 \mu \mathrm{L}$ of10xRSR buffer, $2 \mu \mathrm{L}$ of deoxynucleotide triphosphate (dNTP), $2.5 \mu \mathrm{L}$ of $\mathrm{MgCl} 2$, $2 \mu \mathrm{L}$ of each primer and $0.5 \mu \mathrm{L}$ of Taq DNA polymerase. All components were mixed. The PCR cycles were set by the following stages: Preheating at $95^{\circ} \mathrm{C}$ for $15 \mathrm{~min}$, denaturation at $94^{\circ} \mathrm{C}$ for $1 \mathrm{~min}$, the binding of the primers at $55^{\circ} \mathrm{C}$ for $1 \mathrm{~min}$, elongation at $72^{\circ} \mathrm{C}$ for $30 \mathrm{~min}$ and a final extension at $72^{\circ} \mathrm{C}$ for $30 \mathrm{~min}$. There were 35 cycles in total ( Soumet et al., 1999a). The reaction mixture was prepared using the finished dialing. The PCR results were read by electrophoresis on a $2 \%$ agarose.

\section{Primers selection}

In studying the serotype virulence of Salmonella, the primers were used with a specific oligonucleotide sequence specified in Table 1 and 2.

Table 1: Primers for determination of the serotype virulence of Salmonella

\begin{tabular}{|c|c|c|c|c|c|}
\hline $\mathrm{D}$ & Types & Genes & Sequence & Size & Authors \\
\hline 11 & S. ssp & Inv Agene & $\begin{array}{l}\text { TATCGCCACGTTCGGGCAA } \\
\text { CGCACCGTCAAAGGAACC }\end{array}$ & 378 & Bublitz et al. (2014) \\
\hline 12 & S. ssp & Sal. Ssp & $\begin{array}{l}\text { ATCGCTGACTTATGCAATCG } \\
\text { CGGGTTGCGTTATAGGTCTG }\end{array}$ & 204 & Kwang et al. (1996) \\
\hline 13 & S. typhimurium & DT 104 plasmid & $\begin{array}{l}\text { ATGGGTTTGGTCTCACAGCC } \\
\text { GCTGAGGCCACGGATATTTA }\end{array}$ & 102 & Poppe et al. (1998) \\
\hline 14 & S. cnteritidis & enteritidis & $\begin{array}{l}\text { tctgttttatctgatgcaagagg } \\
\text { tgaactaggttcgttcttctgg }\end{array}$ & 304 & Agron et al. (2001) \\
\hline 15 & S.typhimurum & Typhimurium & $\begin{array}{l}\text { TTGTTCACTTTTTACCCCTGAA } \\
\text { CCCTGACAGCCGTTAGATATT }\end{array}$ & 401 & Hur et al. (2012) \\
\hline 16 & S. spp. & $\mathrm{C}$ group & $\begin{array}{l}\text { ACCGAGCCAACGATTATCAA } \\
\text { AATAGGCCGAAACAACATCG }\end{array}$ & 502 & Luk et al., 1997 \\
\hline
\end{tabular}


D. K. Zhanabayeva et al. / OnLine Journal of Biological Sciences 2021, 21 (3): 235.244 DOI: 10.3844/ojbsci.2021.235.244

Table 2: Primers for determination of antibiotic resistance of Salmonella

\begin{tabular}{|c|c|c|c|c|}
\hline Primers & Sequence & $\begin{array}{l}\text { Genes encoded by } \\
\text { resistance to antibiotics }\end{array}$ & $\begin{array}{l}\text { Size of PCR } \\
\text { product bp }\end{array}$ & Reference \\
\hline blaTEM & $\begin{array}{l}\text { ATGAGTATTCAACATTTCC } \\
\text { GACCAATGCTTAATCAGTGAG }\end{array}$ & gene resistance to Ampicilin & 692 & Gallardo et al. (2003) \\
\hline catA1 & $\begin{array}{l}\text { CGCCTGATGAATGCTCATCCG } \\
\text { CCTGCCACTCATCGCAG TAC }\end{array}$ & gene resistance to chloramphenicol & 878 & Genovese et al. (2004) \\
\hline Sul 1.2 & $\begin{array}{l}\text { GCGCTCAAGGCAGATGGCATT } \\
\text { GCGTTTGATACCGGCACCCGT }\end{array}$ & R- sulfamethoxazole & 293 & Daly and Fanning (2000) \\
\hline Salmonella ssp & $\begin{array}{l}\text { ATCGCTGACTTATGCAATCG } \\
\text { CGGGTTGCGTTATAGGTCTG }\end{array}$ & Sal. Ssp & 204 & Kwang et al. (1996) \\
\hline
\end{tabular}

\section{Electrophoresis}

In general, electrophoresis is described as the migration of charged substances in solutions under the influence of an applied electrical field. The agarose gel analysis was used. The PCR product was lowered to $1,5 \%$ agarose on TBE at 0.5 or TAB (Tris Acetate) at $200 \mathrm{~mL}$ and the PCR material was stained with ethidium bromide $(\mathrm{BrBt})$ for $15 \mathrm{~min}$. Thus, there was a stain and revealed traces of DNA. (Soumet et al., 1999b)

\section{Statistical analysis}

The statistical data reduction was performed using Statistica 6.0 (Stat Soft, USA) and the average error ( $\mathrm{M} \pm$ m) was calculated for each sample taken for analysis.

\section{Results}

Microbiological and molecule-biological research was conducted on 105 samples received. Targeted Bisulfite Sequencing (TBS) defined the presence of coliforms in these samples at different temperature regimes and at different dilutions (Table 3 and 4).

Frozen chicken meat from the Tyson company with MPH 914804 and MHP 487174 certification had the following indicator of microbial contamination: The number of microbes was 3-3.5 times higher, the allowable number of coliforms was 10 times higher and in the thawed meat Targeted Bisulfite Sequencing (TBS) was 2,6 times and in coliforms 2.5 times higher. The frozen meat from Xilingol was 3 times higher, the number of coliforms was twice as high and in the thawed meat TBS was more than $20 \%$ (the number of coliforms $34 \%$ ), (Table 3). The remaining samples had the allowed number of TBS, coliforms and QMAFAnM indicator and did not exceed the rated values.

The samples showed Salmonella and E. coli, studied the nature of the growth of microbes on the classical nutrient media (meat-peptone broth, meat-peptone agar, differential diagnosis - Endo, Levin), formed colonies, Gram stain. The microbiological and molecular-biological research was conducted for a detailed specification.

According to the study of pathogens in the frozen samples from the Tyson company with the MPH 914804 certification, Salmonella was detected (MWCU521698 certification), Listeria monocytogenes (MWCU6027370 certification) and $E$. coli. The chicken meat of the Xilingol company from China showed Salmonella and E. coli. The frozen chickens from the Leghorn company in Russia revealed $E$. coli. The frozen meat of the Mongolian company Tymen shuvuut included E. coli, while the meat of the Khuchit Shonkhor company revealed Salmonella and Pseudomonas.

The research results showed that $9 \%$ of the total sample identified bacteria, such as Salmonella 4\%, EHEC (E. coli serogroup) $4 \%$ and Listeria $1 \%$. Up to $16 \%$ of the pathogenic bacteria substance was found in the American carcass, in the Chinese-produced meat in Mongolia 8\% and Russian 4\%. In 1 gram of meat the CFU (colony forming unit) was below the standard acceptable norm MNS 6308:2012. According to the research on MWCU521698 code, Salmonella spp. was detected 99.99\%; chicken meat from Xilingol company by the code 2044113 had $99.1 \%$ E. coli and samples from Leghorn had $76.99 \%$ of $E$. coli 2 . These data were consistent with data received with standard microbiological methods. With this method, we detected 3304573 Enterobacteria 85,0\%; 5044502 E. coli 2 $76.99 \%$ in the samples from Leghorn, from the meat of the Mongolian Tumen-shuvuut company, the 2342471 Citro.div/amalonat $99,2 \%$ and the Ardager samples 5306562 Serreta liquefaciens 78,4\%. Microbiological methods allocated 5 cultures which were used in the PCR amplification. We studied the Salmonella serotypes and plasmids, the virulence of the gene encoding the antibiotic resistance and transmigration properties of Salmonella. A large absorption of light indicates a high concentration of nucleic acid. These principles determined the DNA yield and its purification. The multiplex method was applied to detect the serum type of Salmonella and S. typhimurium and $S$. enteridis were found in the chicken meat from the United States, S. typhimurium, S. enteridis, S. spp and Salmonella C-group in the meat from Mongolia (Fig. 1).

The chicken meat of the American company Tyson and the Chinese Xilingol revealed $S$. enteridis. PCR was established for the detection of the invA gene (378 bp) and DT 104 Salmonella plasmids (102 bp) (Fig. 2). 
D. K. Zhanabayeva et al. / OnLine Journal of Biological Sciences 2021, 21 (3): 235.244 DOI: 10.3844/ojbsci.2021.235.244

\begin{tabular}{|c|c|c|c|c|c|c|c|c|c|}
\hline \multirow{2}{*}{$\begin{array}{l}\text { Origin of: } \\
\text { Standard }\end{array}$} & \multirow{2}{*}{$\begin{array}{l}\text { Technology } \\
\text { class } \\
\text { 3:2012) }\end{array}$} & \multirow{2}{*}{$\begin{array}{l}\text { Dilution } \\
10^{-1}\end{array}$} & \multirow{2}{*}{$10^{-3}$} & \multirow{2}{*}{$10^{-5}$} & \multicolumn{2}{|l|}{ TBS } & \multicolumn{2}{|l|}{ Coliforms } & \multirow[b]{2}{*}{$\mathrm{p}$} \\
\hline & & & & & Sample & Standard & Sample & Standard & \\
\hline \multirow[t]{2}{*}{ Leghorn } & Frozen & $212 \pm 9$ & $9 \pm 0,4$ & 0 & $6 \times 10^{3}$ & $1 \times 10^{4}$ & $2 \times 10^{1}$ & $1 \times 10^{2}$ & \\
\hline & Thawed & $187 \pm 7$ & $96 \pm 4$ & $5 \pm 0,7$ & $7 \times 10^{3}$ & $5 \times 10^{5}$ & $8 \times 10^{1}$ & $5 \times 10^{2}$ & \\
\hline \multirow[t]{2}{*}{ Xilingol } & Frozen & $290 \pm 11$ & $104 \pm 5$ & & $3 \times 10^{4}$ & $1 \times 10^{4}$ & $2 \times 10^{2}$ & $1 \times 10^{2}$ & $\mathrm{p} \leq 0,05$ \\
\hline & Thawed & $575 \pm 27$ & $700 \pm 27$ & & $6 \times 10^{5}$ & $5 \times 10^{5}$ & $6,7 \times 10^{2}$ & $5 \times 10^{2}$ & \\
\hline \multirow[t]{2}{*}{ Ardager } & Frozen & $412 \pm 15$ & $9 \pm 1$ & 0 & $5,5 \times 10^{3}$ & $1 \times 10^{4}$ & $4 \times 10^{1}$ & $1 \times 10^{2}$ & \\
\hline & Thawed & $169 \pm 7$ & $96 \pm 3$ & $5 \pm 0,12$ & $5 \times 10^{5}$ & $5 \times 10^{5}$ & $9 \times 10^{1}$ & $5 \times 10^{2}$ & \\
\hline \multirow[t]{2}{*}{ Tyson } & Frozen & $286 \pm 13$ & $399 \pm 12$ & & $3,5 \times 10^{4}$ & $1 \times 10^{4}$ & $1 \times 10^{3}$ & $1 \times 10^{2}$ & \\
\hline & Thawed & $801 \pm 22$ & $1987 \pm 46$ & & $1,3 \times 10^{6}$ & $5 \times 10^{5}$ & $2 \times 10^{3}$ & $5 \times 10^{2}$ & \\
\hline \multirow[t]{3}{*}{ TYmen shuvuut } & Cooled & $281 \pm 10$ & $13 \pm 2$ & 0 & $2 \times 10^{3}$ & $3,5 \times 10^{3}$ & $2 \times 10^{2}$ & $1.5 \times 10^{2}$ & \\
\hline & Frozen & $212 \pm 9$ & $9 \pm 1$ & 0 & $4 \times 10^{3}$ & $1 \times 10^{4}$ & $1 \times 10^{1}$ & $1 \times 10^{2}$ & \\
\hline & Thawed & $88 \pm 4$ & $96 \pm 3,5$ & $5 \pm 0,2$ & $2 \times 10^{2}$ & $5 \times 10^{5}$ & $4.5 x * 10^{1}$ & $5 \times 10^{2}$ & \\
\hline \multirow[t]{2}{*}{ Khuchit Shonkhor } & Frozen & $213 \pm 7$ & $9 \pm 2$ & 0 & $2 \times 10^{3}$ & $1 \times 10^{4}$ & $1 \times 10^{1}$ & $1 \times 10^{2}$ & \\
\hline & Thawed & $87 \pm 5$ & $99 \pm 3,2$ & $4,8 \pm 0,3$ & $2 \times 10^{2}$ & $5 \times 10^{5}$ & $4 \times 10^{1}$ & $5 \times 10^{2}$ & \\
\hline
\end{tabular}

Table 4: Pathogenic and conditionally pathogenic microorganisms, $\%$

\begin{tabular}{|c|c|c|c|c|c|c|c|c|c|c|}
\hline \multirow{3}{*}{ No. } & \multirow[b]{3}{*}{$\begin{array}{l}\text { Origin of } \\
\text { the samples: }\end{array}$} & \multirow[b]{3}{*}{$\begin{array}{l}\text { Number of } \\
\text { samples }\end{array}$} & \multicolumn{8}{|c|}{ Bacterium } \\
\hline & & & \multicolumn{2}{|c|}{ Salmonella } & \multicolumn{2}{|l|}{ E. coli } & \multicolumn{2}{|l|}{ Pseudo } & Listeria & S. aureus \\
\hline & & & Number & $\%$ & Number & $\%$ & Number & $\%$ & Number \% & Number $\%$ \\
\hline 1 & Leghorn & 25 & - & - & 1 & & - & - & & 1 \\
\hline 2 & Xilingol & 25 & 1 & - & 1 & & - & - & & 1 \\
\hline 3 & Ardager & 5 & - & - & - & & - & - & & \\
\hline 4 & Tyson & 25 & 2 & & 1 & & - & - & 1 & \\
\hline 5 & TYmen shuvuut & 20 & 1 & - & 1 & & 2 & & & \\
\hline \multicolumn{2}{|c|}{6 Khuchit Shonkhor } & 5 & 1 & & 1 & & 1 & & - & - \\
\hline & Total & 105 & 5 & & 5 & & 3 & & 1 & 2 \\
\hline
\end{tabular}

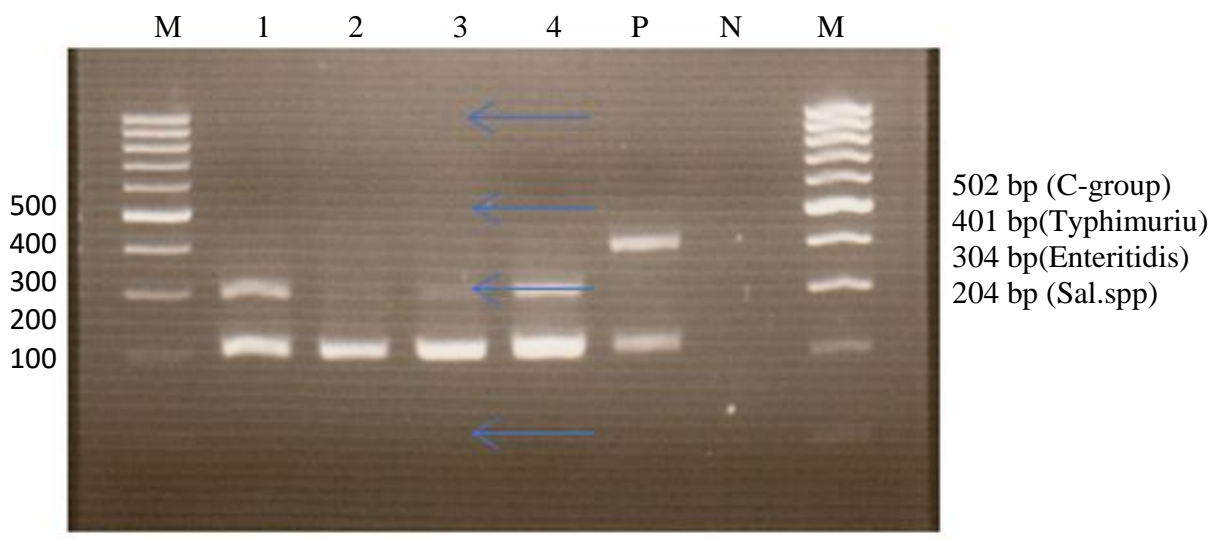

M - Marker (100 bp);

Sample: 1 - 2 USA poultry meat; 3 - Mongolia poultry meat; 4 - Chaina poultry meat;

$\mathrm{P}$ - positive control (S.typhimurium); $\mathrm{N}$ - negative control.

Result: 1 line of Salmonellaspp, S.enteritidis ++ ;

2 line of Salmonellaspp +; 3-4 line of SalmonellasppбaS.enteritidis + +;

$\mathrm{P}-$ positive control S.typhimurium + Salmonellaspp +

Fig. 1: The results of determination of the serum type of salmonella, insulated from poultry meat 


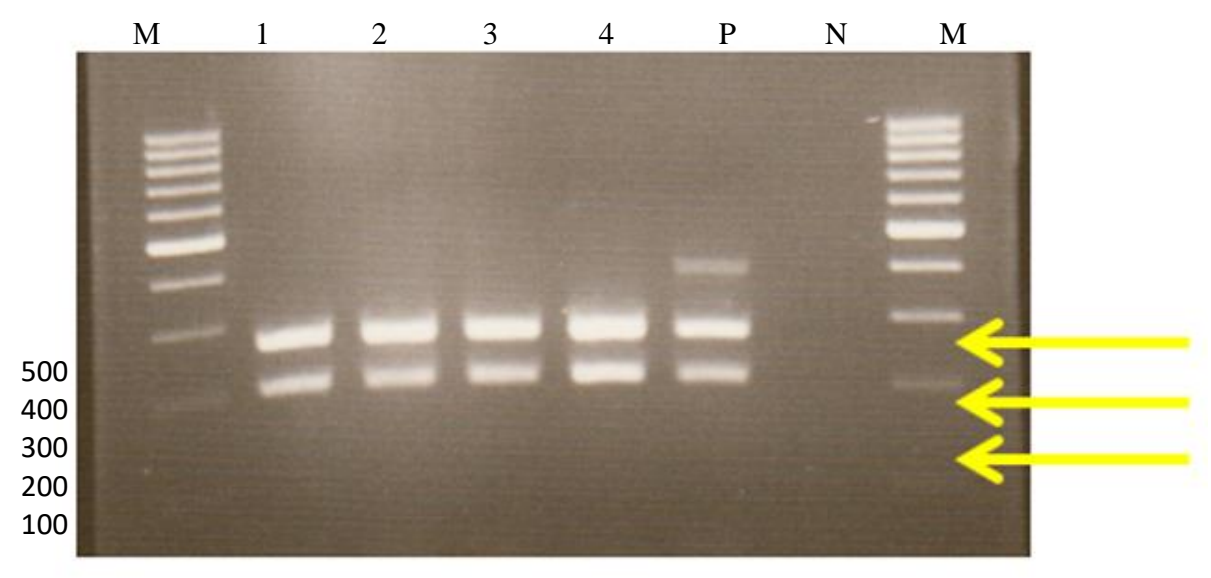

M - Marker (100 bp)

Samples: 1,2 - USA poultry; 3 - Mongolia poultry; 4 - China poultry;

$\mathrm{P}$ - positive control (S.typhimurium); N - negative control

Fig. 2: The results of determining invA gene and DT 104 salmonella plasmids, insulated from poultry

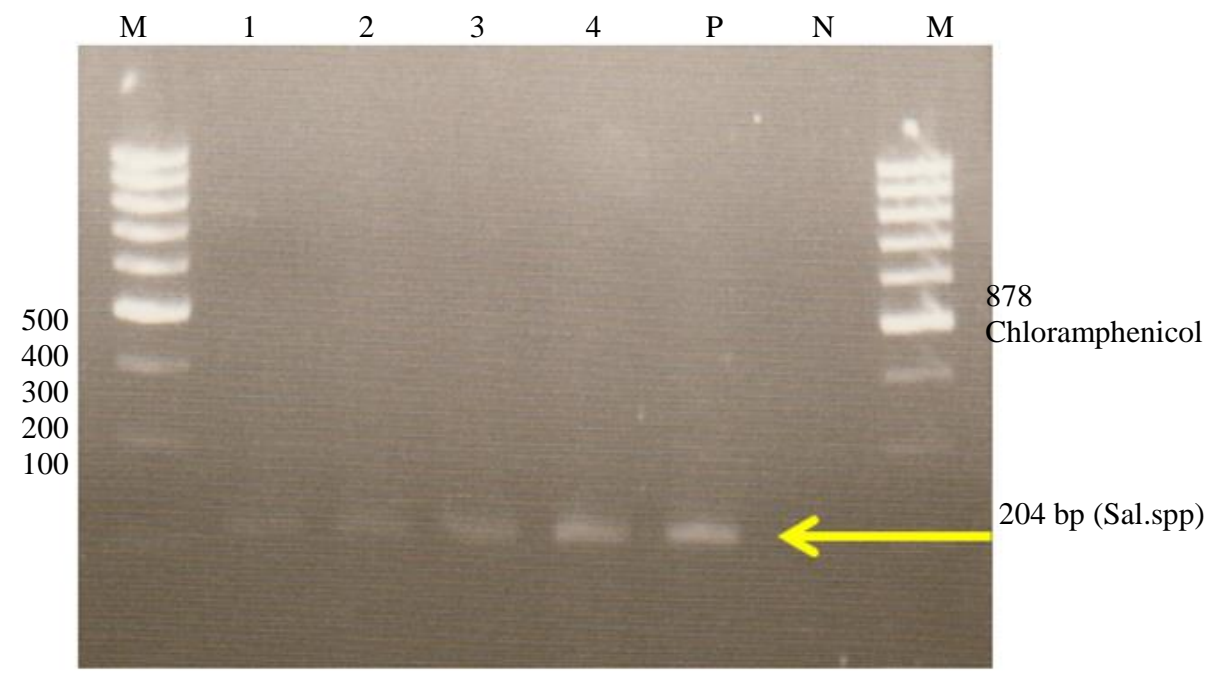

M - Marker (100 bp);

Samples: 1,2 - USA poultry; 3 - Mongolia poultry; 4 - China poultry;

$\mathrm{P}$ - positive control Salmonella spp; $\mathrm{N}$ - negative control.

Fig. 3: The results of determining salmonella, isolated from poultry; resistance to chloramphenicol

General plasmids of Salmonella (204 bp) and invA genes $(278 \mathrm{bp})$ showed positive results. DT 104 genes showed negative results (Fig. 3). This demonstrated the ability of the pathogenic $S$. enteridis to transmigration, but it did not contain any plasmids. According to the results of the PCR and multiplex PCR, $75 \%$ of S. enteridis was found in chicken carcasses, in the rest, other types of Salmonella bacteria. It was detected that Salmonella was positive for a specific gene sequence spp (204 bp) and was biochemically active, which was proven by scanning electrochemical microscopy. We established a PCR for the detection of antibiotic resistance, detected in chicken DNA sequences for $878 \mathrm{bp}$ of chloramphenicol, for ampicillin - 692 bp, for sulfate mycin, 293 bp (Fig. 3).

The results of the definition of sensitivity and resistance of Salmonella from 5 samples of different 
origin, showed that the bacteria were not resistant to chloramphenicol, ampicillin, or sulfate mycin. The Salmonella did not contain a gene encoding resistance. During the study of biological molecules, the virulence and antibiotic resistance of the Salmonella serotype was identified and confirmed within 2-3 days. This reduced the time by 4-5 times, compared with the study on culturing the bacteria by morphological and biochemical analysis. In the study on contamination of chicken meat with microorganisms, it was found that frozen chicken meat from the Tyson company with MPH 914804 certification, as well as the meat from MHP 487174, had the following indicator of microbial contamination: The number of microbes was higher by 3-3.5 times, the allowable number of coliforms was 10 times higher, the TBS in thawed meat in 2.6 times and coliforms 2.5 times higher. The frozen meat from the Elder goal had TBS that was 3 times higher, the number of coliforms was twice as high and the TBS of the thawed meat was more than $20 \%$, with coliforms at $34 \%$.

On the detection of pathogenic microbes in the chicken meat, we received the following data: Salmonella and $E$. coli were present in the samples of one of the American companies with MWCU521698 code number. All this pointed to the possibility of contamination of the products before arrival in Mongolia. The chicken meat from the Xilingol company with outlets based in Ulan Bator revealed Salmonella, E. coli and samples from Leghorn from Russia showed E. coli. The chicken meat, originating from the Mongolian company TYmen shuvuut also revealed $E$. coli. At the Khuchit Shonkhor meat market Salmonella and Pseudomonas, were found, which indicated the increased microbial contamination of poultry during the implementation and transportation stages. According to microbiological research, the frozen meat from America and China had a total number of microbes 3-3.5 times higher than the MNS6308: 2012 standard. That indicated the possibility of the reproduction of pathogenic microbes in these products. The number of microbes in $1 \mathrm{~g}$ of meat reached 100,000 . If the number of bacteria reaches to 3.0 million, the meat becomes dangerous; many microbes may contaminate it in the middle of chopping and cutting, as well as during transport and distribution.

The Salmonella genus has the identified serotype of microbes in beef, 33,3\% cases of S. dublin, 26,7\% S. Enteridis, $21.5 \%$ S. typhimurium, $18.7 \%$ S. chlorsuis, $83,3 \%$ S. anatum, $16.7 \%$ S. chlorsuis and $11,3 \%$ of $S$. enteridis in chicken meat, indicating a significantly greater contamination of meat from these species compared with our data (Nielsen et al., 1995). The InvA genes were identified, DT 104 plasmids and the antibiotic resistance of Salmonella, isolated from poultry, on the DNA sequence for chloramphenicol - $878 \mathrm{bp}$, for ampicillin - 692 bp of, for sulfate mycin - 293 bp. In determining the antigenic structure of Salmonella, isolated from chicken meat, we found that the type of antigen from the Salmonella body is 0.7 ; in flagellate antigen - $\mathrm{H}$ : 5 ; in beef the Salmonella body contained the antigen 0,9 .

\section{Discussion}

Research was conducted on poultry (Janecko et al., 2015) for the presence of and the ability to transport potentially pathogenic substances and microorganisms in Europe and North America from 2010- 2013. However, the experiments were carried out using the tissue samples of Corvidae family birds, which are not used in food (Talib et al., 2015). The development of aviculture in Mongolia as a new branch of the food industry is impossible without the quality control of the meat. Veterinary studies have been conducted on poultry farms, but the quality control of meat products in Mongolia remains unsatisfactory. Therefore, experiments to detect biological contaminants, such as microorganisms and their metabolic products, have become very relevant.

The conducted experiment provides an opportunity to understand the quality and safety of products consumed by the residents of Mongolia. The methods applied in our study can be used for further research material containing potentially dangerous microorganisms. We used multiplex PCR, which is different from previous studies on Salmonella in food products (Chen et al., 1997). We used a similar DNA template for all bacteria definitions. The identification of these microorganisms on different types of DNA template was studied by the precursors (Lampel et al., 2000). In determining the microbial contamination of poultry meat, there is a need to make rational use of toxicogenomics, to deal with global changes in gene expression, in response to either a drug or a toxin and is usually measured using microarrays (mRNA transcription) (Vegh et al., 2013). As one of the most popular types of meat, pork is constantly susceptible to scrutiny for the presence of pathogens (Swaminathan and Feng, 1994), but the meat of birds from private property is checked less frequently than wild poultry meat (Janecko et al., 2015). Eggs are also an important part of the production industry in Mongolia; therefore, it makes sense to apply the existing methods and to carry out monitoring and detection of pathogens in the future (Chen and Griffiths, 1996).

The stability of the studied objects to certain antibiotics opens up the possibility for the further study of these objects, or finding the synthesis of substances, to which these bacteria are not resistant. Studying the mechanisms of creation and implementation of Salmonella and E. coli pathogens will provide an opportunity to influence the processes of synthesis of these compounds or block their action (Lin and Tsen, 1996).

Adapted to the conditions of modern laboratories of sanitary-epidemiological services, it can serve as a tool for diagnosing the products before being distributed. 


\section{Conclusion}

Almost $70 \%$ of the food that Mongolia needs is imported. According to the report of a specialized laboratory in 2010 , $12.4 \%$ of imported products have been tested for quality and safety. Most of the products were contaminated with pathogenic microbes and potentially pathogenic.

We identified the virulence of genes and plasmids DT 104 in the species of the Salmonella genus. These were detected in the presence of pathogenic and opportunistic pathogenic microorganisms, which indicated the level of danger.

The results showed:

- Compliance with a sanitary-hygienic regime is necessary at all stages of the food cycle

- Monitoring of the quality of products, both imported and produced in Mongolia, needs to be tightened

- The methods of investigating food sanitary and epidemiological services need to improve

- Meat must be heat-treated to prevent foodborne disease

- $\quad$ The need for further research on products, which may contain potentially pathogenic organisms and the classification of these organisms

- The need for the study of pathogens for the detection of substances, which eliminate their effects

\section{Author's Contributions}

All authors equally contributed in this study.

\section{Ethical Considerations}

This article is original and contains unpublished material. The authors declare that are no ethical issues and no conflict of interest that may arise after the publication of this manuscript.

\section{References}

Agron, P. G., Walker, R. L., Kinde, H., Sawyer, S. J., Hayes, D. C., Wollard, J., \& Anderse, G. L., (2001). Identification by subtractive hybridization of sequences specific for Salmonella enterica serovar Enteritidis. Applied and Environmental Microbiology, 67(11), 4984-4991. https://doi.org/10.1128/aem.67.11.4984-4991.2001

Bublitz, D. C., Wright, P. C., Bodager, J. R., Rasambainarivo, F. T., Bliska, J. B., \& Gillespie, T. R., (2014). Epidemiology of Pathogenic Enterobacteria in Humans, Livestock and Peridomestic Rodents in Rural Madagascar. PLoS ONE, 9(7); e101456. http://doi.org/10.1371/journal.pone.0101456
Chen, J., \& Griffiths, M. W. (1996). Salmonella detection in eggs using lux+ bacteriophages. Journal of Food Protection ${ }^{\circ}, \quad 59(9) ; \quad 908-914$. https://doi.org/10.4315/0362-028x-59.9.908

Chen, S., Yee, A., Griffiths, M., Larkin, C., Yamashiro, C. T., Behari, R., Razsko-Kolva, C., Rahn, K., \& De Grandis, S. A. (1997). The evaluation of a fluorogenic polymerase chain reaction assay for the detection of Salmonella species in food commodities. International Journal of Food Microbiology, 35(3): 239-250. https://doi.org/10.1016/s0168-1605(97)01241-5

D’Aoust, J. Y., \& Maurer, J., (2007). Salmonella species. In: Food Microbiology: Fundamentals and Frontiers, Doyle, M., \& Beuchat, L. (Eds.), Third Edition, American Society of Microbiology, pp: 187-236. ISBN-10: 9781555814076.

Daly, M., \& Fanning, S. (2000). Characterization and chromosomal mapping of antimicrobial resistance genes in Salmonella enterica serotype Typhimurium. Applied and Environmental Microbiology, 66(11), 4842-4848. https://doi.org/10.1128/aem.66.11.48424848.2000

Everhart, J. E., \& Ruhl, C. E. (2009). Burden of digestive diseases in the United States part II: lower gastrointestinal diseases. Gastroenterology, 136(3), 741-754. https://doi.org/10.1053/j.gastro.2009.01.015

Gallardo, F., Ruiz, J., Soto, S. M., Jimenez de Anta, M. T., \& Vila, J. (2003). Distintos mecanismos de resistencia asociados a integrones en aislamientos clínicos de Salmonella typhimurium [Different antibiotic resistance mechanisms associated with integrons in clinical isolates of Salmonella typhimurium]. Revista Española de Quimioterapia, 16(4), 398-402. https://pubmed.ncbi.nlm.nih.gov/14961133/

Garrido, A., Chapela, M. J., Román, B., Fajardo, P., Lago, J., Vieites, J. M., \& Cabado, A. G. (2013). A new multiplex real-time PCR developed method for Salmonella spp. and Listeria monocytogenes detection in food and environmental samples. Food Control, 30(1), 76-85. https://doi.org/10.1016/j.foodcont.2012.06.029

Genovese, K. J., Jung, Y. S., McReynolds, J. L. anderson, R. C., \& Nisbet, D. J. (2004). Antimicrobial resistance and serotype prevalence of Salmonella isolated from dairy cattle in the southwestern United States. Microbial Drug Resistance, 10(1), 51-56. https://doi.org/10.1089/107662904323047808

Hur, J., Stein, B. D., \& Lee, J. H. (2012). A vaccine candidate for post-weaning diarrhea in swine constructed with a live attenuated Salmonella delivering Escherichia coli K88ab, K88ac, FedA and FedF fimbrial antigens and its immune responses in a murine model. Canadian Journal of Veterinary Research, 76(3), 186-194. 
Janecko, N., Čížek, A., Halová, D., Karpíšková, R., Myšková, P., \& Literák, I. (2015). Prevalence, characterization and antibiotic resistance of Salmonella isolates in large corvid species of Europe and North America between 2010 and 2013. Zoonoses and Public Health, 62(4), 292-300. https://doi.org/10.1111/zph.12149

Khosrof, B. J. S., Jiridi, M., Fodha, M., \& Salem, I. (2002). [Study of Salmonella contamination of restaurant meat products collected over a period of one year]. La Tunisie Medicale, 80(4), 207-213.

Kwang, J., Littledike, E. T., \& Keen, J. E. (1996). Use of the polymerase chain reaction for Salmonella detection. Letters in Applied Microbiology, 22(1), 46-51. https://doi.org/10.1111/j.1472-765x.1996.tb01106.x

Lampel, K. A., Orlandi, P. A., \& Kornegay, L. (2000). Improved template preparation for PCR-based assays for detection of food-borne bacterial pathogens. Applied and Environmental Microbiology, 66(10), 4539-4542. https://doi.org/10.1128/aem.66.10.4539-4542.2000

Lin, C. K., \& Tsen, H. Y. (1996). Use of two 16S DNA targeted oligonucleotides as PCR primers for the specific detection of Salmonella in foods. Journal of Applied Bacteriology, 80(6), 659-666. http://doi.org/10.1111/j.1365-2672.1996.tb03271.x

Luk, J. M., Kongmuang, U., Tsang, R. S., \& Lindberg, A. A. (1997). An enzyme-linked immunosorbent assay to detect PCR products of the rfbS gene from serogroup D salmonellae: a rapid screening prototype. Journal of Clinical Microbiology, 35(3), 714-718. https://doi.org/10.1128/jcm.35.3.714-718.1997

Lynch, M. F., Tauxe, R. V., \& Hedberg, C. W. (2009). The growing burden of foodborne outbreaks due to contaminated fresh produce: risks and opportunities. Epidemiology and Infection, 137(03), 307-315. https://doi.org/10.1017/s0950268808001969

Nielsen, B., Baggesen, D., Bager, F., Haugegaard, J., \& Lind, P. (1995). The serological response to Salmonella serovars typhimurium and infantis in experimentally infected pigs. The time course followed with an indirect anti-LPS ELISA and bacteriological examinations. Veterinary Microbiology, 47(3), 205-218. https://doi.org/10.1016/0378-1135(95)00113-1

Norman, S. A., Hobbs, R. C., Wuertz, S., Melli, A., Beckett, L. A., Chouicha, N., Kundu, A., \& Miller, W. A. (2013). Fecal pathogen pollution: Sources and patterns in water and sediment samples from the upper Cook Inlet, Alaska ecosystem, 15(5): 1041-1051. http://doi.org/10.1039/c3em30930d

Poppe, C., Smart, N., Khakhria, R., Johnson, W., Spika, J., \& Prescott, J. (1998). Salmonella typhimurium DT104: a virulent and drug-resistant pathogen. The Canadian Veterinary Journal, 39(9), 559-565.
Sarimehmetoglu, B., \& Kuplulu, O. (2001). Isolation and identification of motile Aeromonas species from chicken. DTW. Deutsche Tierarztliche Wochenschrift, 108(11), 465-467.

Soumet, C., Ermel, G., Rose, N., Rose, V., Drouin, P., Salvat, G., \& Colin, P. (1999a). Evaluation of a multiplex PCR assay for simultaneous identification of Salmonella sp., Salmonella Enteritidis and Salmonella Typhimurium from environmental swabs of poultry houses. Letters in Applied Microbiology, 28(2), 113-117. https://doi.org/10.1046/j.1365-2672.1999.00488.x

Soumet, C., Ermel, G., Rose, N., Rose, V., Drouin, P., Salvat, G., \& Colin, P. (1999b). Identification by a multiplex PCR-based assay of Salmonella Typhimurium and Salmonella Enteritidis strains from environmental swabs of poultry houses. Letters in Applied Microbiology, 29(1), 1-6. https://doi.org/10.1046/j.1365-2672.1999.00559.x

Strawn, L. K., Danyluk, M. D., Worobo, R. W., \& Wiedmann, M. (2014). Distributions of Salmonella subtypes differ between two US produce-growing regions. Applied and Environmental Microbiology, 80(13), 3982-3991. https://doi.org/10.1128/aem.00348-14

Swaminathan, B., \& Feng, P. (1994). Rapid detection of food-borne pathogenic bacteria. Annual Reviews in Microbiology, 48(1), 401-426. https://doi.org/10.1146/annurev.mi.48.100194.002153

Talib, A., Afendy, M. \& Radu, S. (2015). Pre-enrichment effect on PCR Detection of Salmonella Enteritidis in artificially-contaminated raw chicken meat. International Food Research Journal, 22(6), 2571-2576.

Tavechio, A. T., Ghilardi, Â. C. R., Peresi, J., Fuzihara, T. O., Yonamine, E. K., Jakabi, M., \& Fernandes, S. A. (2002). Salmonella sterotypes isolated from nonhuman sources in São Paulo, Brazil, from 1996 through 2000. Journal of Food Protection $®$, 65(6), 1041-1044.

https://doi.org/10.4315/0362-028x-65.6.1041

Tibaijuka, B., Molla, B., Hildebrandt, G., \& Kleer, J. (2002). Occurrence of Salmonellae in retail raw chicken products in Ethiopia. Berliner Und Munchener Tierarztliche Wochenschrift, 116(1-2), 55-58.

Vegh, P., Foroushani, A. B. K., Magee, D. A., McCabe, M. S., Browne, J. A., Nalpas, N. C., Conlon, K. M., Gordon, S. V., Bradley, D. G., MacHugh, D. E. \& Lynn, D. J. (2013). Profiling microRNA expression in bovine alveolar macrophages using RNA-seq. Veterinary Immunology and Immunopathology, 155(4), 238-244. http://doi.org/10.1016/j.vetimm.2013.08.004 
Wang, R., Cao, W., \& Cerniglia, C. E. (1997). A universal protocol for PCR detection of 13 species of foodborne pathogens in foods. Journal of Applied Microbiology, 83(6), 727-736. https://doi.org/10.1046/j.1365-2672.1997.00300.x

Whyte, P., Mc Gill, K., Collins, J. D., \& Gormley, E. (2002). The prevalence and PCR detection of Salmonella contamination in raw poultry. Veterinary Microbiology, 89(1), 53-60. https://doi.org/10.1016/s0378-1135(02)00160-8

Wilson, I. G. (2002). Salmonella and Campylobacter contamination of raw retail chickens from different producers: a six year survey. Epidemiology and Infection, 129(03), 635-645. https://doi.org/10.1017/s0950268802007665
Worcman-Barninka, D., Destro, M. T., Fernandes, S. A., \& Ladgraf, M. (2001). Evaluation of motility enrichment on modified semi-solid RappaportVassiladis medium (MSRV) for the detection of Salmonella in foods. International Journal of Food Microbiology, 64(3), 387-393. https://doi.org/10.1016/s0168-1605(00)00484-0

Zhao, C., Ge, B., De Villena, J., Sudler, R., Yeh, E., Zhao, S., White, D. G., Wagner, D., \& Meng, J. (2001). Prevalence of Campylobacter spp., Escherichia coli and Salmonella serovars in retail chicken, turkey, pork and beef from the Greater Washington, DC, area. Applied and Environmental Microbiology, 67(12), 5431-5436. https://doi.org/10.1128/aem.67.12.5431-5436.2001 